\title{
Novel Cationic Schiff Base Surfactants: Surface Studies and Biocidal Activities against Bacteria Fungi and Sulfate Reducing Bacteria
}

\author{
M.F. Zaky, A. M. Badawi, H. A. Ead" and M. M. Aboulimoud \\ Petrochemicals Department, Egyptian Petroleum Research \\ Institute and ${ }^{*}$ Faculty of Science, Cairo University, Cairo, Egypt.
}

\begin{abstract}
OVEL series of cationic Schiff base surfactants were synthesized and characterized using microelemental analysis, FTIR and ${ }^{1} \mathrm{H}-$ NMR spectra. The properties of the synthesized surfactant solutions such as critical micelle concentration $(\mathrm{CMC})$, effectiveness $\left(\Pi_{\mathrm{CMC}}\right)$, surface excess concentration $\left(\Gamma_{\max }\right)$, surface area $\left(\mathrm{A}_{\min }\right)$ and free energy of micellization $\left(\Delta \mathrm{G}_{\mathrm{mic}}\right)$ were determined using surface tension measurements. These Schiff base surfactants were evaluated for their antibacterial activity against Gram positive and Gram negative bacteria and fungi. The results of the biocidal activities revealed high potent action of the Schiff bases towards bacteria and fungi. The biocidal activity of the tested compounds against sulfur (sulfate) reducing bacteria (SRB) showed promising results in the area of oil field applications.
\end{abstract}

Keywords: Cationic surfactants, Schiff-base, Micellization, Adsorption, Surface properties, Biocidal activity and Sulfate reducing bacteria.

Cationic surfactants are classes of compounds having one or more hydrophobic group attached to a positively charged atom ${ }^{(1)}$. Cationic surfactants application are in cosmetics, cleaners and bactericides, oil recovery and micro- and mesoporous structures (zeolites) applications ${ }^{(2-4)}$. Schiff bases are considered good antibacterial compounds due to the easily preparing procedures and their ability to attach to several function groups. Schiff bases have been studied extensively because of their high potential chemical permutation. Antibacterial, antifungal ${ }^{(5-7)}$, antitumour, anticancer, and antiviral activities ${ }^{(8-10)}$ of Schiff bases have been reported.

Sulfur reducing bacteria have been treated as phenotypic group which are found in different phylogenetic lines. Sulfur reducing bacteria gain their energy from reduction of elemental sulfur or its components into $\mathrm{H}_{2} \mathrm{~S}$. They grow inside septic tank lines and cause rapid deterioration of concrete and reinforcing steel therein. The resistance route against SRB is based on using efficient cationic or metal complex compounds. Examples of biocides used are quaternary ammonium hydroxide ${ }^{(11)}$, Schiff base of pyrolidione, pyridone with ophenylenediamine and their metal complexes ${ }^{(12)}$. Metallomicelles are effective biocide for different types of bacteria ${ }^{(13)}$. In this work, a series of Schiff base cationic surfactants were synthesized and evaluated for their potent action 
against different bacterial strains including pathogenic bacteria, sulfur reducing bacteria (SRB) and fungi.

\section{Synthesis}

\section{Experimental}

Synthesis of Schiff base (SB)

The Schiff base under investigation was synthesized throughout condensation reaction between 0.1 mole of p-aminobenzoic acid and 0.1 mole of 3pyridinecarboxaldehyde that were refluxed in $100 \mathrm{ml}$ of methanol as a solvent for 8 $\mathrm{hr}$. The reaction mixture was left to cool overnight and then filtered. The product was recrystallized from methanol and finally dried under vacuum at $40{ }^{\circ} \mathrm{C}$ to afford pale yellow crystals of the corresponding pyridine Schiff base (yield 93\%, m.p. $60-62{ }^{\circ} \mathrm{C}$ ). The chemical structure of the produced Schiff base is represented in Scheme 1.
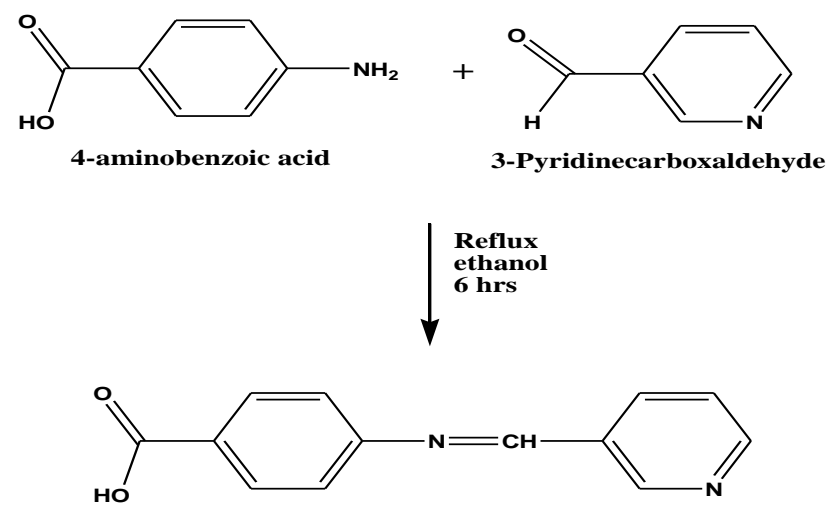

SB: 4-((pyridin-3-yl)methyleneamino)benzoic acid
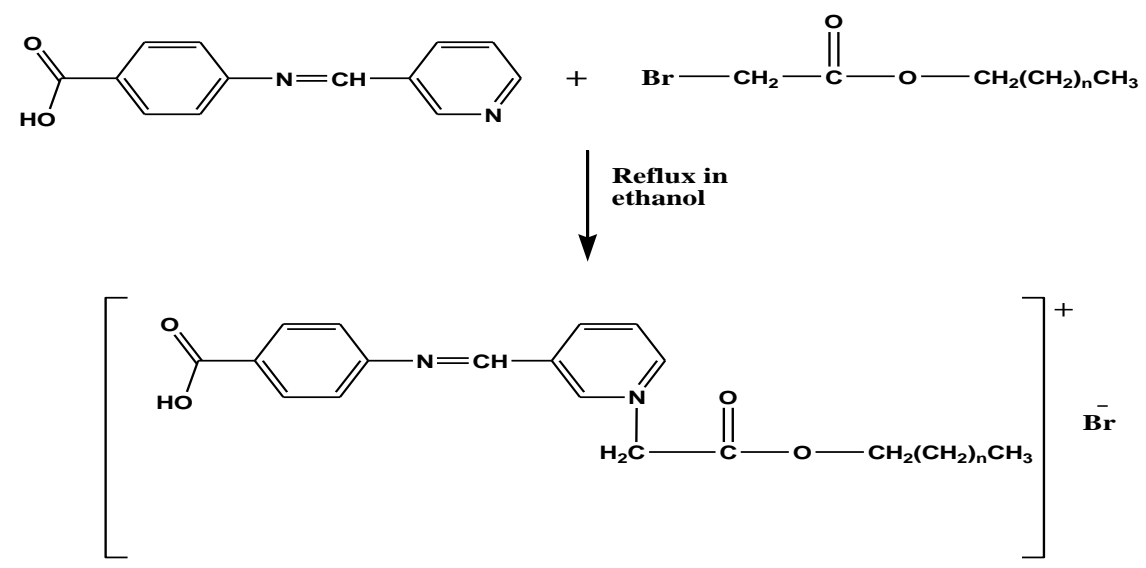

where n=6: SB8; $n=10$ : SB12; $n=14:$ SB16; $n=16:$ SB18

Scheme .1. Synthesis of cationic Schiff base surfactants.

Egypt. J. Chem. 55, No. 2 (2012) 
Synthesis of the fatty alcohol ester of bromoacetic acid (C8-18)

Bromoacetic acid (0.1 mol.) and fatty alcohol including: octanol, dodecanol, hexadecanol and octadecanol $(0.1 \mathrm{~mol}$.) were esterified individually in xylene as a solvent and in presence of $0.01 \%$ p-toluene sulphonic acid as a catalyst. The mixture was refluxed until the azeotropic amount of water $(1.8 \mathrm{ml})$ was removed. After removal of the solvent, the catalyst was removed from the reaction product by extracting in petroleum ether ${ }^{(14)}$. to afford the different fatty alcohol esters of bromoacetic acid. The products were symboled as (C8) for octyl bromoacetate, (C12) for dodecyl bromoacetate, (C16) for hexadecyl bromoacetate and (C18) for octadecyl bromoacetate esters.

Preparation of quaternary cationic surfactants

The prepared Schiff base (SB) was quaternized individually by the prepared $\mathrm{C} 8, \mathrm{C} 12, \mathrm{C} 16$ and $\mathrm{C} 18$ in presence of ethanol as a solvent to produce the desired quaternary ammonium Schiff base surfactants which were designated as SB8 for octyl derivative, SB12 for dodecyl derivative, SB16 for hexadecyl derivative and SB18 for octadecyl derivative ${ }^{(15)}$.

\section{Instruments}

Elemental analyses were performed using Vario elemental instrument. FTIR spectra were performed using Fourier-transformer infrared spectrophotometer. ${ }^{1} \mathrm{H}-\mathrm{NMR}$ spectra were performed using Bruker model DRX-300 NMR spectrometer with TMS as an internal standard.

\section{Surface and interfacial tension measurements $(\gamma)$}

The surface tension of freshly prepared aqueous solution of SB8, SB12, SB16 and SB18 in concentration range of 0.0025-0.00001 mol L ${ }^{-1}$ at $25{ }^{\circ} \mathrm{C}$ was measured with a Krüss K-6 tensiometer (Hamburg, Germany) using Du Noüy platinum ring detachment method and was calibrated using deionized water at $25^{\circ} \mathrm{C}$. The readings were taken in triplicate for each solution to check repeatability and the surface tension values were within an error less than or equal to $\pm 1 \mathrm{mN} / \mathrm{m}^{(16)}$. The interfacial tension measurements were obtained between aqueous solution of the synthesized cationic Schiff bases at concentration of $0.1 \mathrm{wt} \%$ and light paraffin oil at $25{ }^{\circ} \mathrm{C}$ using identical procedures of the surface tension measurements ${ }^{(17,18)}$.

\section{Antimicrobial studies}

The synthesized cationic Schiff base surfactants were screened for their antimicrobial activity against bacteria and fungi using agar well diffusion method ${ }^{(19)}$.

\section{Analyses}

\section{Results and Discussion}

Microelemental analyses of the synthesized Schiff bases showed their purity $\approx$ $98 \%$ ( Table1). IR spectra showed strong and broad band at $(2500-3500) \mathrm{cm}^{-1}$ due to the $\mathrm{OH}$ group of the acid, absorption band at $850-890 \mathrm{~cm}^{-1}$ corresponding to the benzene nucleus. The presence of absorption band at $1718 \mathrm{~cm}^{-1}$ indicates 
the formation of $\mathrm{C}=\mathrm{O}$ ester group. The disappearance of the two bands at 1735 and $3315 \mathrm{~cm}^{-1}$ due to the carbonyl $v(\mathrm{C}=\mathrm{O})$ and $v(\mathrm{NH} 2)$ stretching vibrations and the appearance of a strong new band at $1692 \mathrm{~cm}^{-1}$ determines the formation of azomethene $v(\mathrm{HC}=\mathrm{N})$ linkage. The absorption bands at 2858 and $2926 \mathrm{~cm}^{-1}$ correspond to the stretching of the two groups $\mathrm{CH}_{2}$ and $\mathrm{CH}_{3}$ in the fatty chains.

${ }^{1} \mathrm{H}-\mathrm{NMR}$ spectra: $0.96 \mathrm{ppm}\left(\mathrm{S}, 6 \mathrm{H}, \mathrm{CH}_{3}\right) ; 1.29 \mathrm{ppm}\left(\mathrm{m}, \mathrm{nH}, \mathrm{CH}_{2}\right)($ where $\mathrm{n}=$ $16 \mathrm{H}$ decanoate, $28 \mathrm{H}$ hexadecanoate, $32 \mathrm{H}$ octadecanoate) and $4.08 \mathrm{ppm}(\mathrm{T}, 2 \mathrm{H}$,$\left.\mathrm{OCH}_{2}\right) ; 2.4 \mathrm{ppm}\left(\mathrm{s}, 2 \mathrm{H}, \mathrm{CH}_{2}-\mathrm{CO}\right)$ and $8.7 \mathrm{ppm} ; 9.5 \mathrm{ppm} ; 9.7 \mathrm{ppm}$ and $9.9 \mathrm{ppm}$ for pyridinium peaks; $11 \mathrm{ppm}(\mathrm{S}, 1 \mathrm{H}, \mathrm{OH}$-carboxylic )

TABLE 1. Elemental analysis of the synthesized Schiff base cationic surfactants.

\begin{tabular}{|c|c|c|c|c|c|c|c|c|}
\hline \multicolumn{10}{|c|}{ Microelemental analysis } \\
\hline \multirow{2}{*}{ Comp. } & \multicolumn{2}{|c|}{ \% C } & \multicolumn{2}{c|}{ \% H } & \multicolumn{2}{c|}{ \% N } & \multicolumn{2}{|c|}{ \% Br } \\
\cline { 2 - 9 } & Calc. & Found & Calc. & Found & Calc. & Found & Calc. & Found \\
\hline $\begin{array}{c}\text { SB8 } \\
(477.39)\end{array}$ & 57.87 & 57.46 & 6.12 & 6.08 & 5.87 & 5.83 & 16.74 & 16.62 \\
\hline $\begin{array}{c}\text { SB12 } \\
(533.50)\end{array}$ & 60.79 & 60.36 & 6.99 & 6.94 & 5.25 & 5.21 & 14.98 & 14.87 \\
\hline $\begin{array}{c}\text { SB16 } \\
(589.61)\end{array}$ & 63.51 & 62.71 & 7.69 & 7.64 & 4.75 & 4.72 & 13.55 & 13.46 \\
\hline $\begin{array}{c}\text { SB18 } \\
(617.66)\end{array}$ & 64.17 & 63.72 & 8.00 & 7.94 & 4.54 & 4.50 & 12.94 & 12.85 \\
\hline
\end{tabular}

\section{Surface activity}

Figure1 represents the variation of the surface tension against log conc. of SB8, SB12, SB16 and SB18 at $25{ }^{\circ}$ C. The profile showed sharp break points corresponding to the critical micelle concentration values of the different surfactants $^{(20)}$. The values of the surface tension appeared relatively high compared to the conventional cationic surfactants, That may be due to the presence of the aromatic rings in the molecules. Also, it could be observed that increasing the number of methylene groups along the hydrophobic chains from 12 to 18 units increases the critical micelle concentrations considerably (Fig. 2). That can be explained according to the previous work ${ }^{(21)}$ due to the assumption of repulsion between the hydrophobic chains and the water phase, which forces the surfactant molecules to micellize in the bulk of their solutions in order to decrease that repulsion. On the other hand, increasing the hydrophobic chain length from 8 to 12 methyl groups $\left(-\mathrm{CH}_{2}-\right)$ improves the surface activities as the $\mathrm{C} 8$ is not considered as surfactant ${ }^{(22)}$.

The highest CMC values were observed at $3.98 \mathrm{mM}$ and $3.16 \mathrm{mM}$ for SB8 and SB18, respectively while the lowest value was observed for SB12 at 1.26 $\mathrm{mM}$ at $25{ }^{\circ} \mathrm{C}$, which referred to the above reasons. The efficiency values $\left(\mathrm{Pc}_{20}\right)$

Egypt. J. Chem. 55, No. 2 (2012) 
of the synthesized surfactants are defined as the concentration of the amphiphiles solutions that decreases the surface tension to $51 \mathrm{mNm}^{-1}$ calculated using the data in Fig.1. The $\mathrm{Pc}_{20}$ values describe the ability of surfactant molecules to adsorb at the interface and also indicate the accumulation extent of the surfactant molecules at the interface. The increase in the hydrophobic chain length of the studied amphiphiles, results in fast decrease in the surface tension of the surfactant solution indicating the high tendency of the longer hydrophobic molecules to adsorb at the interface. The lowest $\mathrm{Pc}_{20}$ value is observed to SB12.

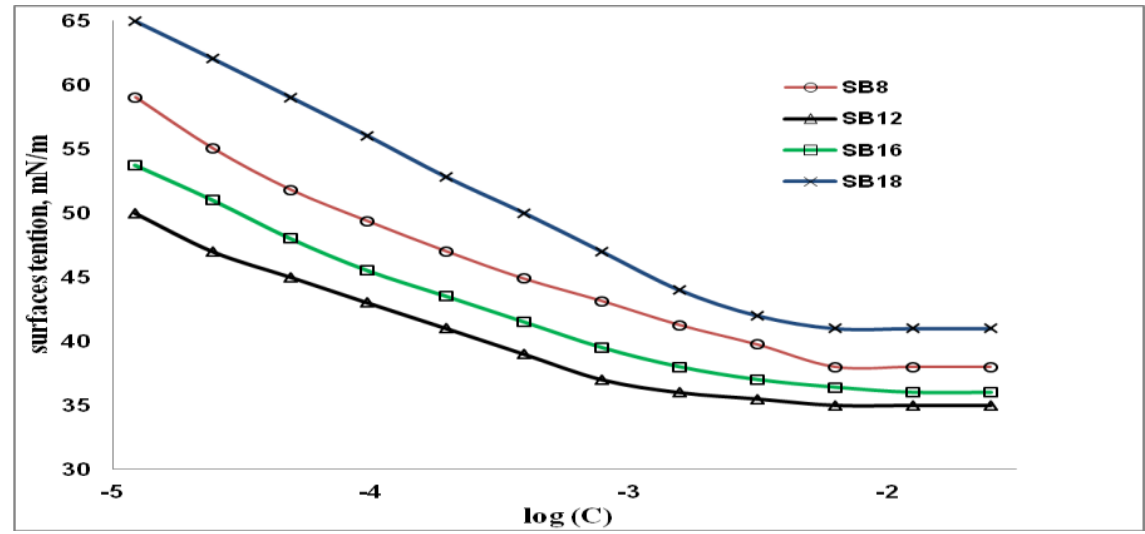

Fig.1. The relation between the surface tension and log concentration of the synthesized cationic Schiff base amphiphiles at $25 \circ \mathrm{C}$

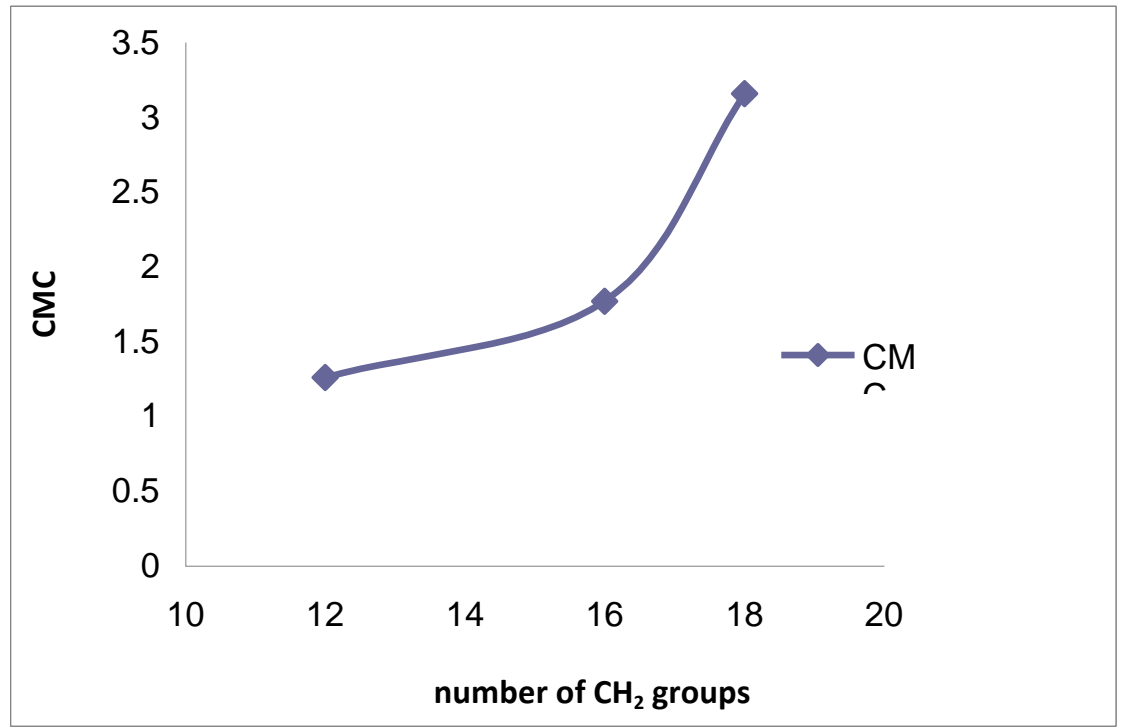

Fig.2. Effect of hydrophobic chain length on the CMC. 
Values of the minimum surface area occupied by the cationic Schiff-base amphiphiles at the interface $\left(\mathrm{A}_{\min }\right)$ were calculated according to the equation:

$$
\mathrm{A}_{\min }=10^{16} /\left(N_{A V} \cdot \Gamma_{\max }\right)
$$

where, $\Gamma_{\max }$ and $\mathrm{N}_{\mathrm{AV}}$ are the maximum surface excess and Avogadro's number, respectively.

The minimum surface area is the area occupied by each molecule at the interface and it depends on the chemical structure of the surfactant molecules hence when the hydrophobic chain length increases (the number of the methylene groups increase) the area of occupied gby each molecule at air-water interface increases. The minimum surface area of the Schiff base cationic surfactants are listed in Table 2.

TABLE 2. Surface properties of the synthesized cationic Schiff bases at $25 \circ \mathrm{C}$.

\begin{tabular}{|c|c|c|c|c|c|c|c|}
\hline Compound & $\begin{array}{c}\mathbf{C M C}^{\mathbf{a}} \\
(\mathbf{m m o l} / \mathbf{l})\end{array}$ & $\begin{array}{c}\mathbf{P i} \mathbf{~ m m c ~}^{\mathbf{a}} \\
(\mathbf{m N / m})\end{array}$ & $\begin{array}{c}\mathbf{P c}_{\mathbf{2 0}} \\
(\mathbf{m m o l} / \mathbf{l})\end{array}$ & $\begin{array}{c}\boldsymbol{\Gamma}_{\mathbf{m a x}} \mathbf{X 1 0}^{-\mathbf{1 0}} \\
\left(\mathbf{m o l K}^{-1} \mathbf{m}^{-\mathbf{1}}\right)\end{array}$ & $\begin{array}{c}\mathbf{A}_{\mathbf{m i n}} \\
\left(\mathbf{n m}^{\mathbf{2}}\right)\end{array}$ & $\boldsymbol{\Delta} \mathbf{G}_{\mathbf{m i c}}$ & $\Delta \mathbf{G}_{\mathbf{a d s}}$ \\
\hline SB8 & 3.98 & 33.4 & 0.0891 & 3.12 & 53.2 & -13.4 & -14.47 \\
\hline SB12 & 1.26 & 36.6 & 0.00794 & 2.68 & 61.9 & -16.2 & -17.55 \\
\hline SB16 & 1.77 & 35.6 & 0.0245 & 2.83 & 58.6 & -15.36 & -16.61 \\
\hline SB18 & 3.16 & 31.2 & 0.281 & 3.92 & 42.28 & -13.96 & -14.75 \\
\hline
\end{tabular}

$\Gamma_{\text {max }}=(-\mathrm{d} \gamma / \mathrm{d} \log C) /(\mathrm{RT})$;

$\Delta G_{\text {mic }}=[2.303 \mathrm{RT} \log (\mathrm{CMC})]-[\log (55.5)]$;

$\Delta G_{\text {ads }}=\Delta G_{m i c}-\left(0.6023 \times 10^{-2} \times \Pi_{\mathrm{CMC}} \times A_{\text {min }}\right)$.

\section{Thermodynamics of adsorption and micellization}

The micellization and adsorption processes of the amphiphiles molecules occurred instantly, but commonly one process may be predominating than the other. The predominance of any of the two processes is governed by the thermodynamic variables of this process. In the studied surfactants, both adsorption and micellization thermodynamic functions are calculated based on the methodology of Rosen ${ }^{(23)}$ and using the surface activity data in Table 2 . The free energy changes of micellization and adsorption showed negative sign, indicating the spontaneously of the two processes at $25^{\circ} \mathrm{C}$. Also, it is clear that when the hydrophobic chain length of the synthesized Schiff base surfactants increases, $\Delta \mathrm{G}_{\mathrm{mic}}$ and $\Delta \mathrm{G}_{\mathrm{ads}}$ increase. Also, the slight increase of $\Delta \mathrm{G}_{\mathrm{ads}}$ values may be ascribed to the tendency of the molecules to adsorb at the air-water interface until complete surface coverage and the slight increase of $\Delta \mathrm{G}_{\mathrm{mic}}$ values indicates the tendency of the surfactant molecules to migrate to the bulk of solution to form micelle. Also, the negativity values of $\Delta \mathrm{G}_{\text {ads }}$ are greater than the corresponding $\Delta \mathrm{G}_{\text {mic }}$. This indicates the tendency of surfactant molecules to be adsorbed at the air-water interface rather than escape to the bulk of their solutions to form micelles. The tendency towards adsorption is refereed to the interaction between the aqueous phase and the hydrophobic chains which pumps

Egypt. J. Chem. 55, No. 2 (2012) 
the amphiphile molecules to the interface. The presence of these amphiphiles at the interface decreases the phase interaction.

Interfacial tension $\left(\gamma_{\text {int }}\right)$

The interfacial tension values of the cationic Schiff base surfactants against paraffin oil at $25{ }^{\circ} \mathrm{C}$ are represented in Fig. 3 which indicates that the interfacial tension value of $\mathrm{SB} 8$ is $3.0 \mathrm{mN} / \mathrm{m}$ and it increases with increasing the hydrophobic chain length to reach $6.0 \mathrm{mN} / \mathrm{m}$ for SB18 surfactant.

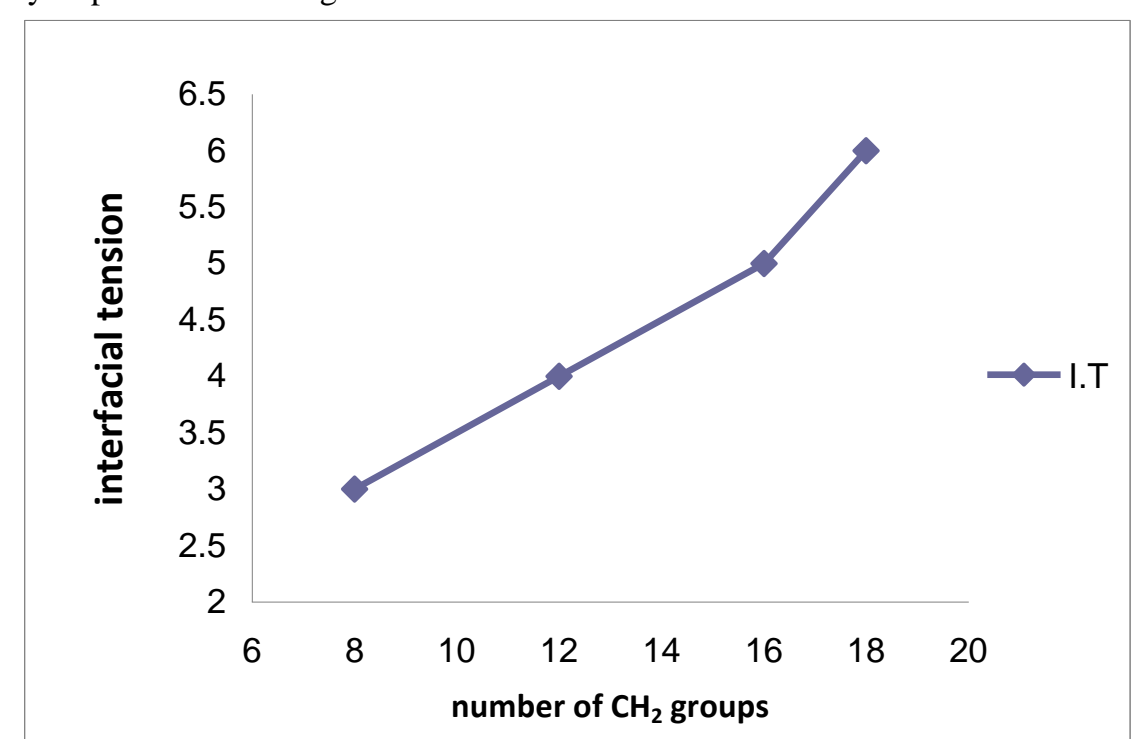

Fig. 3. Relation between hydrophobic chain length and the interfacial tension.

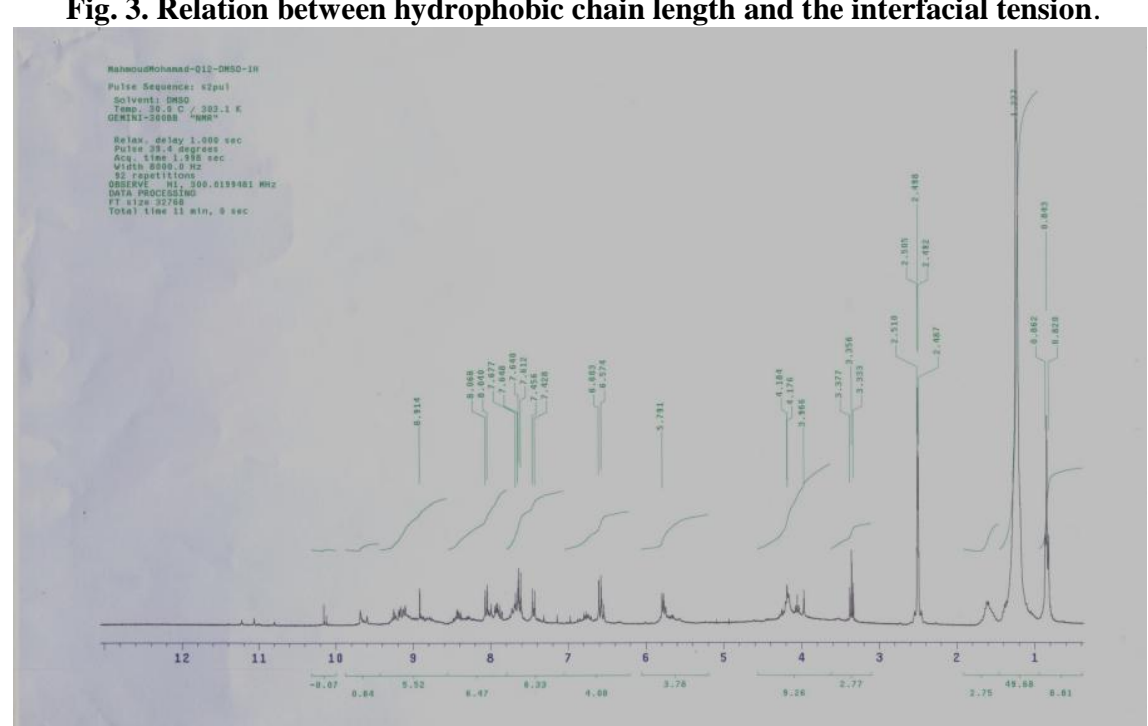

Fig. 4. H NMR spectra of cationic surfactant.

Egypt. J. Chem. 55, No. 2 (2012) 
Biological activity

Table 3 represents the antibacterial and antifungal activities of the prepared cationic Schiff bases using well diffusion method against Gram-positive, Gramnegative bacteria and fungi. Cetyl trimethyl ammonium bromide and Grisofluvine were taken as the reference drugs for antibacterial and antifungal activities, respectively. The synthesized cationic Schiff- base amphiphiles showed good biocidal activity against Micrococcus, Sarcina sp. and Pencillium. These results are in good agreements with the results of several investigators dealt with the cationic surfactants ${ }^{(24,25)}$. The hydrophobic chain length has a remarkable influence on the biological activities of the targeted compounds. Increasing the hydrophobic chain length increases the antifungal activity to great extent while, the antibacterial activities are increased gradually.

Antimicrobial activity of prepared cationic surfactants against sulfate-reducing bacteria $(S R B)$

The results of antimicrobial activity of the synthesized cationic surfactant biocides against SRB were determined and listed in Table 4. The sulfur reducing bacteria (as a potent type of Gram negative bacteria) are characterized by a thick cellular membrane, so that these microorganisms have high resistance against bacterial biocides. Consequently, the creation of efficient antimicrobial agents against the Gram negative bacteria is considered a promising step in the biocidal field. The synthesized surfactants showed good biocidal activity against D. pigra strain and the maximum inhibition efficiency was reported to compound (SB8) which produces inhibition zone diameter of $20 \mathrm{~mm}$ per $\mathrm{mg}$ inhibitor. The biocidal activities of the synthesized cationic Schiff base surfactants against SRB are arranged in the following arrangement: SB8 $>$ SB12 $>$ SB16 $=$ SB18.

TABLE 3. Biological activity of the synthesized cationic Schiff bases.

\begin{tabular}{|c|c|c|c|c|c|c|}
\hline \multirow{2}{*}{ Compounds } & \multicolumn{6}{|c|}{ Inhibition zone diameter (mm) } \\
\cline { 2 - 7 } & \multicolumn{7}{|c|}{ Bacteria } & \multirow{2}{*}{ Yeast } & \multirow{2}{*}{ Fungi } \\
\cline { 2 - 7 } & $\begin{array}{c}\text { Gram positive } \\
\text { Bacillus } \\
\text { pumilus }\end{array}$ & $\begin{array}{c}\text { Micrococcus } \\
\text { sp. }\end{array}$ & $\begin{array}{c}\text { Pseudomonas } \\
\text { aeruginosa }\end{array}$ & Sarcina sp. & $\begin{array}{c}\text { Candida } \\
\text { albicans }\end{array}$ & \multirow{2}{*}{ Pencillium } \\
\hline SB8 & 14 & 21 & 15 & 15 & --- & 21 \\
\hline SB12 & --- & 21 & 14 & 17.6 & --- & 16 \\
\hline SB16 & 16 & 16 & 13 & 18 & 16 & 17 \\
\hline SB18 & --- & 17 & --- & 19 & 17 & 16 \\
\hline blank & 14 & 13 & 13 & 14 & 15 & 16 \\
\hline
\end{tabular}


TABLE 4. Antimicrobial activity of prepared cationic surfactants against desulfomonas pigra (SRB).

\begin{tabular}{|c|c|}
\hline Compound & Desulfomonas pigra $(\mathbf{m m} / \mathbf{m g})$ \\
\hline SB8 & 20 \\
\hline SB12 & 15 \\
\hline SB16 & 11 \\
\hline SB18 & 11 \\
\hline Stander: tetracycline & 26 \\
\hline
\end{tabular}

\section{References}

1. Madaan, P. and Vinod, K. Tyagi, Quaternary pyridine salts : A Review. J. Oleo Sci. 57 (4), 197-215(2008).

2. Richmond, J.M. (Ed.) Cationic Surfactants: Organic Chemistry; New York: Marcel Dekker (1990)

3. Rubingh, D.N. and Holland, P.M. (Ed.) Cationic Surfactants: Physical Chemistry; New York: Marcel Dekker (1991)

4. Cross, J. and Edward, J. Singer, (Ed.) Cationic Surfactants: Analytical and Biological Evaluation; New York: Marcel Dekker (1994)

5. Singh, K., Barwa, M.S. and Tyagi, P., Synthesis, characterization and biological studies of $\mathrm{Co}(\mathrm{II}), \mathrm{Ni}(\mathrm{II}), \mathrm{Cu}(\mathrm{II})$ and $\mathrm{Zn}$ (II) complexes with bidentate Schiff bases derived by heterocyclic ketone. Eur. J. Med. Chem. 41,147-53 (2006).

6. Panneerselvam, P., Nair, R.R., Vijayalakshmi, G., Subramanian, E.H. and Sridhar, S.K., Synthesis of Schiff bases of 4-(4-aminophenyl)-morpholine as potential antimicrobial agents. Eur. J. Med. Chem. 40, 225-225 (2006).

7. Pandeya, S.N., Sriram, D., Nath, G. and Declercq, E., Synthesis, antibacterial, antifungal and anti-HIV activities of Schiff and Mannich bases derived from isatin derivatives and N-[4-(4'-chlorophenyl)thiazol-2-yl] thiosemicarbazide. Eur. J. Pharm. Sci. 9, 25-31(1999).

8. Mladenova, R., Ignatova, M., Manolova, N., Petrova, T. and Rashkov, I., Preparation, characterization and biological activity of Schiff base compounds derived from 8hydroxyquinoline-2-carboxaldehyde and Jeffamines ED. Eur. Polym. J. 38, 989-99 (2002). 
9. Phatak, P., Jolly, V.S. and Sharma K.P., Synthesis and biological activities of some substituted aryl azo Schiff base. Orient J. Chem. 16, 493-494 (2000).

10. El-Sharkawy, H.A. and Badawi, A.M., Synthesis and biocidal activity of some novel tin-based cationic surfactants res. J. Agric. \& Biol. Sci. 4, 257-264 (2008).

11. Badawi, A.M., Hegazy, M.A., El-Sawyb, A.A., Ahmed, H.M., Kamel, W.M., Novel quaternary ammonium hydroxide cationic surfactants as corrosion inhibitors for carbon steel and as biocides for sulfate reducing bacteria (SRB). Materials Chemistry and Physics, 124, 458-465(2010).

12. Gaur, S., Physico-chemical and biological properties of $\mathrm{Mn}(\mathrm{II}), \mathrm{Co}(\mathrm{II}), \mathrm{Ni}(\mathrm{II}), \mathrm{Cu}(\mathrm{II})$ chelates of Schiff bases. Asian J. Chem. 15, 250-254 (2003).

13. Badawi, A., Negm, N. and El-Zahar, S., Biocidal activity of some novel cationic Metallomicelles. Metal Ions in Biology and Medicine, 8, 89-95 (2004).

14. Negm, N.A., Surface activities and electrical properties of long chain diquaternary bola-form amphiphiles. Egypt. J. Chem. 45, 3, 483-499 (2002).

15. Negm, N.A., El-Farargy, A., Mahmoud, S.A., Zaki, M.F. and Abdel Rahman, N., Cationic Schiff base amphiphiles: Synthesis, characterization and surface activities of cationic surfactants bearing Schiff base groups and their $\mathrm{Mn}(\mathrm{II}), \mathrm{Cu}(\mathrm{II})$ and $\mathrm{Co}(\mathrm{II})$ complexes. Egypt. J. Petrol. 17, 15-25 (2008).

16. Negm, N.A. and Mahmoud S., Effect of structure on the physicochemical properties of nonionic phosphate amphiphiles. Egypt. J. Petrol. 13, 1-95 (2003)

17. Zaki, M.F., Negm, N.A., Salem, M.A.I. and Badawi, A.M., Synthesis, surface and thermodynamic properties of some novel methyl diethanol ammonium bromide as cationic surfactants. $7^{\text {th }}$ International Conference of Chemical Engineering, Cairo, Egypt, December 27-29(2004).

18. Negm, N.A. and Mohamed, A.S., Synthesis, characterization and biological activity of sugar-based gemini cationic amphiphiles. JSD, 11, 215-221(2008).

19. Jain, M., Singh, V. and Singh, R., Biologically potent sulphonamide imine complexes of organotin (IV). Journal of the Iranian Chemical Society. 1, 20-27 (2004).

20. Sugihara, G., Miyazono, A., Nagadome, S., Oida, T., Hayashi, Y., Jeong-Soo K.O., Adsorption and micelle formation of mixed surfactant systems in water II: a combination of cationic gemini-type surfactant with MEGA-10. J Oleo Sci. 52,449458 (2003).

21. Zaki, M.F., Synthesis, surfaces properties and biocidal activity of 2-amino-1naphthol-4-sulfonate triethanolamine monoalkanoate cationic surfactants. Egypt. J. Petrol. 17, 15-21 (2008).

22. Negm, N.A., Said, M.M. and Morsy, Salwa M.I., Pyrazole derived cationic surfactants and their tin and copper complexes: Synthesis, surface activity, antibacterial and antifungal efficacy. J. Surfact. Deterg. 13, 521-528 (2010).

Egypt. J. Chem. 55, No. 2 (2012) 
23. Rosen, M.J., Surface and Interfacial Phenomena; New York: Wiley (1989).

24. Negm, N.A., Zaki, M.F. and Salem, M.A.I., Cationic schiff base amphiphiles and their metal complexes: Surface and biocidal activities against bacteria and fungi. Colloids and Surfaces B: Biointerfaces, 77, 96-103 (2010)

25. Negm, N.A., Morsy, S.M.I. and Said, M.M., Biocidal activity of some mannich base cationic derivatives. J. Bioorg. Med. Chem. 13, 5921-5926 (2005)

(Received 1/7/ 2012;

accepted 30/7/2012)

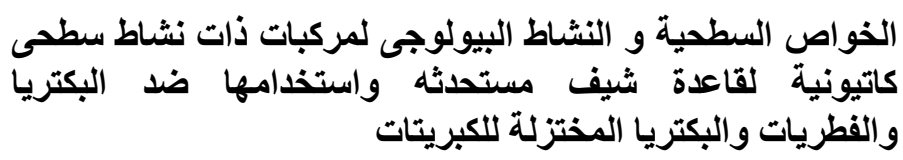

محمد فحمى ذكى، عبد الفتاح محسن بدوى، حامد عبد الرحيم عيد" ومحمود

قسم البتروكيماويات - معهد بحوث البترول و *كلية العلوم - جامعة القاهرة -

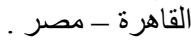

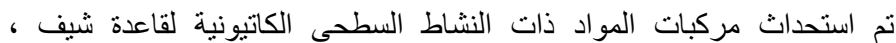

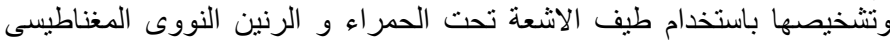

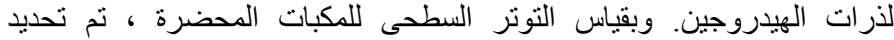

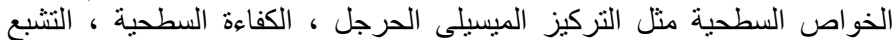

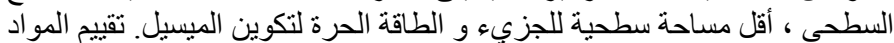

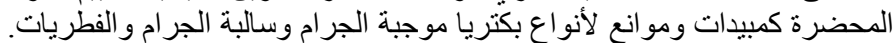

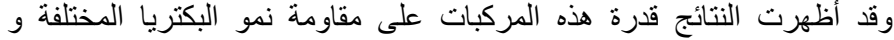

الفطريات و المركبات التي تم تحضيرهات هات نتائج مرغوبة كمبارية كبيدات لنمو البكتيريا

المختزلة للكبريتات فى مجآل البترول. 